\title{
Importance of using ATM
}

\author{
D.Raviteja, R Ravimohan, S.Venkatraman
}

\begin{abstract}
Information advancement is a snappy creating fragment now day by day. Step by step new manifestations are happening in market. In fiscal part especially the monetary division there are such an enormous number of new advancements are happening in cash related operations.ATM is a noteworthy improvement for banking portion. The supernatural occurrences of present day advancement have made it functional for bank customers to interface with an electronic monetary office as Automated Teller Machine (ATM) instead of with an individual for cash trades. Electronic banking is one of the most modern organizations offered by for all intents and purposes all banks to their customers. Electronic banking incorporates among others, Automated Teller Machine (ATM), Point-Of-Sale (POS), and Telephone banking, and so on. The amazing cost of setting up and working full-organization branch work environments has driven starting late to a sharp augmentation in obliged organization workplaces, for instance, Automated Teller Machines (ATMs) [19],[21],[23]
\end{abstract}

Keywords : ATM Access, Point-Of-Sale, electronic monetary

\section{INTRODUCTION}

The An automated teller machine or customized teller machine (ATM) is a device that outfits the clients of money related establishments with access to trade trades out an open space without the need of bank customers. [14],[ 16], [18]The front line ATMs, the customer is perceived by embeddings an ATM card with a chip that contains an uncommon card number and a couple of data, for instance, a slip by date, CVV(Card Value Verification) code and customer name. Customer unmistakable evidence and affirmation is given by the customer giving an individual distinctive confirmation number (PIN). [25],[27],[29]Using an ATM system, customers can get to their monetary adjusts to benefit withdrawals, platinum card store advances, and check their record balance. Distortion against ATM structure and people's endeavor to use them takes a couple of methodologies. [8],[10], [12] At the point when customer's bank card is lost and the mystery expression is known, the software engineer will draw all the money in the constrained capacity to center time, which conveys colossal money hardships to customer. [13], [15] ,[ 17]Not in any way like

Revised Manuscript Received on July 22, 2019.

D.Raviteja Student,,Department of MBA,Bharath institute of Higher Education \& Research,Tamilnadu,India Email:raviteja@gmail.com

Mr R Ravimohan Assistant Professor,Department of MBA,Bharath institute of Higher Education \& Research,Tamilnadu,India Email: rajmohanravimohan@gmail.com

S.Venkatraman, Assistant Professor,Department of Civil,Bharath institute of Higher Education \& Research,Tamilnadu,India Email: mailmagik@yahoo.com bank system, ATMs does not require any individual playing out the trade to display his picture ID, for instance, sign and his physical proximity. If the bank card is stolen by the culprit and the PIN number is known, a criminal individual can without quite a bit of a stretch make a passageway to the money related parity. There has moreover been bundle of scenes of criminal by the Man-in-the-middle attacks, where hooligans have affixed card perusers or fake keypads to the present ATM machines. These fake keypads will be used to examine customers' PINs and trade mystery word to make unapproved access to the bank customers. [1],[3],[5]

\section{DATA COLLECTION}

Primary data has been collected through questionnaire. A sample size of 15 respondents has been taken. [20],[22], [24] Secondary data on the other hand are those which have been already collected by someone else and which have already been passed through the statistical processes. E.g., books, magazines, internet, publications and report. [31],[33]

\section{RESULTS}

Research Methodology may be implicit as a science of studying how the research has been done scientifically. It is a way to methodically solve the research problem. [2 ],[4],[6]

Here, we study and analyze the various steps that are generally adopted by a researcher in studying his problems. The primary methods of data collection that is questionnaire technique was used to collect the data required. No of Respondents include both male and female [7],[9] ,[11]

TABLE 1People having accounts in bank

\begin{tabular}{|l|l|l|}
\hline Particulars & respondent & Percentage \\
\hline SBI & 6 & 40 \\
\hline ICICI & 4 & 27 \\
\hline HDFC & 5 & 33 \\
\hline UNION BANK & 0 & 0 \\
\hline OTHERS & 0 & 0 \\
\hline
\end{tabular}

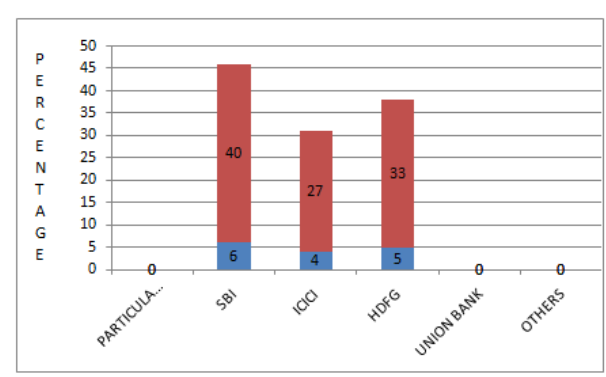




\section{Importance of using ATM}

\section{REFERENCES}

1) BharthVajan R., Ramachandran S.,Psychographic dimensions of training,2016,International Journal of Pharmacy and Technology,V-8,I-4,P-23727-23729

2) Balakrishnan P., Bharthvajan R.,A study on human resource planning in hospitals in Chennai City,2014,International Journal of Applied Engineering Research,V-9,I-22,P-7503-7507

3) Priyadarsini P., Bharthvajan R.,Role of emotional intelligence training programme in reducing the stress of the nurses,2014,International Journal of Applied Engineering Research,V-9,I-22,P-7411-7421

4) Kerinab Beenu G., Bharthvajan R.,Empirical analysis on the cosmetic buying behavior of young women in South India,2014,International Journal of Applied Engineering Research,V-9,I-22,P-7361-7366

5) Balakrishnan P., Bharthvajan R.,Whistling in the wind,2014,International Journal of Applied Engineering Research,V-9,I-22,P-7586-7593

6) Krishnan B., Peter M.,Health hazards of Indian Bpo employee-an alarming issue,2014,International Journal of Applied Engineering Research,V-9,I-22,P-7336-7341

7) Kerinab Beenu G.H., Peter M.,Role of insurance in economic development,2014,International Journal of Applied Engineering Research,V-9,I-22,P-7532-7539

8) Balakrishnan P., Peter M., Priyadarsini P.,Efficiency of safety measures for wellbeing of employees in manufacturing industry,2014,International Journal of Applied Engineering Research,V-9,I-22,P-7376-7382

9) Anbarasi M., Praveen Kumar S.,Online sales promotions of herbal products and its effectiveness towards tanisha.com,2019, Indian Journal of Public Health Research and Development,V-10,I-1,P-195-200

10) Anbarasi M., Praveen Kumar S.,Various online marketing and promotions strategies to improve the validation towards the organic products in the pharmaceutical sectors,2019,Indian Journal of Public Health Research and Development,V-10,I-1,P-263-269

11) Loganathan R., Praveen Kumar S.,Grievance handling a key factor for solving issues of employees in an organization,2014,International Journal of Applied Engineering Research,V-9,I-22,P-7483-7491

12) Loganathan R., Praveen Kumar S.,Study on preference of private label brands in super and Hypermarkets,2014,International Journal of Applied Engineering Research,V-9,I-22,P-7327-7335

13) Smitha M., Praveen Kumar S.,Understanding stress and its managementamong the nurses in Chennai city,2014,International Journal of Applied Engineering Research,V-9,I-22,P-7560-7565

14) Kerinab Beenu G.H., Praveen Kumar S.,A study on the investment behavior of Chennai investors in mutual fund schemes,2014,International Journal of Applied Engineering Research,V-9,I-22,P-7520-7525

15) Loganathan R., Praveen Kumar S.,Retention strategies key for organizational productivity,2014,International Journal of Applied Engineering Research,V-9,I-22,P-7443-7447

16) Pavithra J., Ganesan M., Brindha G.,State wise analysis of microfinance sector in India,2016,International Journal of Pharmacy and Technology,V-8,I-4,P-23417-23432

17) Pavithra J., Ganesan M.,A comparative study on microfinance in India and abroad,2016,International Journal of Applied Business and Economic Research,V-14,I-8,P-5471-5476

18) Pavithra J., Ganesan M.,A study on awareness and impact of micro-financial schemes,2016,International Journal of Applied Business and Economic Research,V-14,I-8,P-5449-5460

19) Senthilmurugan P., Pavithra J.,Consumer preference towards organised retailing with reference to Big Bazaar,2014,International Journal of Applied Engineering Research,V-9,I-22,P-7469-7475

20) Senthilmurugan P., Pavithra J.,Implication of social media marketing in growing healthcare industry,2014,International Journal of Applied Engineering Research,V-9,I-22,P-7448-7456

21) Loganathan R., Pavithra J.,Consumer perception towards private label brand over other brands in super markets and hypermarkets,2014,International Journal of Applied Engineering Research,V-9,I-22,P-7355-7360

22) Kerinab Beenu G., Pavithra J.,Tradeâ€"off between liquidity and profitability in logistics industry,2014,International Journal of Applied Engineering Research,V-9,I-22,P-7398-7401

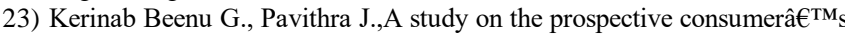
perception towards utility cars in Chennai city,2014,International Journal of Applied Engineering Research,V-9,I-22,P-7526-7531

24) Pavithra J., Dilli Babu P., Ambuli T.V.,A study on budgetary control at Maruti Service Masters, Chennai,2014,International Journal of Applied Business and Economic Research,V-12,I-2,P-151-161

25) Pavithra J., Dilli Babu P., Ambuli T.V.,A study on customer satisfaction of retro Garments Pvt Ltd, Chennai,2014,International Journal of Applied Business and Economic Research,V-12,I-2,P-381-391
26) Kerinab Beenu G.H., Pavithra J., Senthilmurugan P.,A study on the influence of promotional activities for TATA ARIA among consumers in Chennai,2014,International Journal of Applied Engineering Research,V-9,I-22,P-7572-7578

27) Vijayaragavan S.P.,An investigative expert that's general FBG sensors,International Journal of Mechanical Engineering and Technology,V-8,I-8,PP-1500-1505,Y-2017

28) Vijayaragavan S.P.,Equalization routing protocol for Wi-Fi sensor strategy,International Journal of Mechanical Engineering and Technology,V-8,I-8,PP-1662-1666,Y-2017

29) Karthik B., Kiran Kumar T.V.U., Vijayaragavan P., Bharath Kumaran E.,Design of a digital PLL using 0.35 $\hat{\mathrm{I}}^{1 / 4 \mathrm{~m}}$ CMOS technology,Middle East Journal of Scientific Research,V-18,I-12,PP-1803-1806,Y-2013

30) Kanniga E., Selvaramarathnam K., Sundararajan M.,Kandigital bike operating system,Middle - East Journal of Scientific Research,V

31) Jasmin M., Vigneshwaran T., Beulah Hemalatha S.,Design of power aware on chip embedded memory based FSM encoding in FPGA,International Journal of Applied Engineering Research,V-10,I-2,PP-4487-4496,Y-2015

32) Jasmin M.,Optimization techniques for low power VLSI circuits,Middle East Journal of Scientific Research,V-20,I-9,PP-1082-1087,Y-2014

33) Jasmin M., Vigneswaran T.,Fuzzy controller for error control of on - Chip communication,2017 International Conference on Algorithms, Methodology, Models and Applications in Emerging Technologies, ICAMMAET 2017,V-2017-January,I-,PP-1-5,Y-2017

\section{AUTHORS PROFILE}

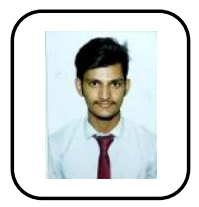

D.Raviteja Student,,Department of MBA,Bharath institute of Higher Education \& Research,Tamilnadu,India

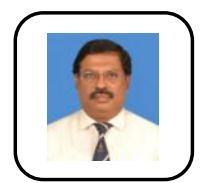

Mr R Ravimohan Assistant Professor,Department of MBA,Bharath institute of Higher Education \& Research,Tamilnadu,India

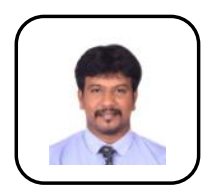

S.Venkatraman, Assistant Professor,Department of Civil,Bharath institute of Higher Education \& Research,Tamilnadu,India 